Conservation implications of exporting domestic wood harvest to neighboring countries

Mayer, A.L.

Elsevier

2006

Mayer, A.L. et al. 2006. Conservation implications of exporting domestic wood harvest to neighboring countries. Environmental Science \& Policy 9: 228-236.

http://hdl.handle.net/1975/445

Downloaded from Helda, University of Helsinki institutional repository.

This is an electronic reprint of the original article.

This reprint may differ from the original in pagination and typographic detail.

Please cite the original version. 


\title{
Conservation implications of exporting domestic wood harvest to neighboring countries
}

\author{
Audrey L. Mayer ${ }^{a, *}$, Pekka E. Kauppi ${ }^{b}$, Päivi M. Tikka ${ }^{b}$, Per K. Angelstam ${ }^{c}$ \\ ${ }^{a}$ US Environmental Protection Agency, Office of Research and Development, National Risk Management Research Laboratory, \\ 26 W. Martin Luther King Dr., MS498, Cincinnati, OH 45268, USA \\ ${ }^{\mathrm{b}}$ University of Helsinki, Department of Biological and Environmental Sciences, PO Box 27, 00014 Helsinki, Finland \\ ' Swedish University of Agricultural Sciences, Faculty of Forest Sciences, School for Forest Engineers, SE-739 21 Skinnskatteberg, Sweden
}

\section{A R T I C L E I N F O}

Published on line 20 February 2006

Keywords:

Boreal forest

International trade

Conservation

Finland

Russia

\begin{abstract}
A B S T R A C T
Among wealthy countries, increasing imports of natural resources to allow for unchecked consumption and greater domestic environmental conservation has become commonplace. This practice can negatively affect biodiversity conservation planning if natural resource harvest is merely pushed across political borders. As an example, we focus on the boreal forest ecosystem of Finland and northwest Russia. While the majority of protected forests are in northern Finland, the majority of biodiversity is in southern Finland, where protection is more difficult due to high private ownership, and the effectiveness of functioning conservation networks is more uncertain due to a longer history of land use. In northwest Russia, the current protected areas are inadequate to preserve most of the region's naturally dynamic and old growth forests. Increased importation of wood from northwest Russia to Finland may jeopardize the long-term viability of species in high diversity conservation areas in both Russia and Finland, through isolating conservation areas and lowering the age of the surrounding forest mosaic. The boreal forest ecosystem of Fennoscandia and northwest Russia would thus be best conserved by a large scale, coordinated conservation strategy that addresses long-term conservation goals and wood consumption, forest industries, logging practices and trade.
\end{abstract}

(c) 2006 Elsevier Ltd. All rights reserved.

\section{Introduction}

Historically, nature conservation has usually occurred domestically, as unique or inspiring landscapes were preserved for recreation, or private hunting and harvesting. Such conservation areas ranged from publicly owned national parks in the United States to the woods and gardens of royal families in Europe (Davenport and Rao, 2002). Landscape conservation has also been driven by the need for products and services supplied by intact ecosystems. For example, conserving forested land in the Catskills watershed was motivated by the demand for a secure water supply for New York City (Chichilinsky and Heal, 1998). With increasing awareness of the current global species extinction crisis, conservation concern has shifted to a more global scale, through prioritizing areas supporting high species diversity ("hotspots") or endemic and endangered species, especially in tropical biomes (Prendergast et al., 1993; Myers et al., 2000). These different motivations can result in conflicting advice on which lands to conserve or restore. While a focus on domestic habitat

\footnotetext{
* Corresponding author at: University of Tampere, Research Centre Synergos, Yliopistonkatu 54, FIN-33100 Tampere, Finland. Tel.: +358 33551 8380; fax: +358 335518537 .

E-mail address: audrey.mayer@uta.fi (A.L. Mayer). 1462-9011/\$ - see front matter (C) 2006 Elsevier Ltd. All rights reserved. doi:10.1016/j.envsci.2005.12.002
} 
conservation may be positive for biodiversity in the short term, exporting the displaced natural resource extraction can endanger domestic biodiversity in the long term if the protected and exploited areas are ecologically connected. Biodiversity conservation, therefore, needs to occur at relevant spatial and temporal scales, not just those relevant for political or economic reasons.

The "environmental Kuznets curve" concept predicts that environmental damage - such as natural resource extraction, which leads to species loss - is highest in societies at intermediate levels of income, where demand for economic growth outweighs demand for environmental protection (Dietz and Adger, 2003). This pattern may not hold in practice, especially if countries with high incomes export their environmental footprint and natural resource extraction to areas with lower incomes and environmental protection (Brachares et al., 2004). When goods production can be geographically separated from consumption through international trade, the point at which environmental deterioration decreases with rising income may be delayed or never realized (Khanna and Plassmann, 2004). Exporting wood harvest to meet domestic demand for consumption and forest protection is common (Sedjo, 1995; Sohngren et al., 1999; Berlik et al., 2002; Leppänen et al., 2005). Ignoring the complicated relationship between biodiversity conservation, income and international trade can frustrate conservation efforts at many scales (Adams et al., 2004; Brachares et al., 2004).

Here, we analyze a case in the boreal region, wherein high income and demand for forest protection in Finland has coincided with an increase in imported wood logged from northwestern Russia. We note that in this case, shifting extraction beyond Finland's border may eventually be to the detriment of not only the last remaining natural forests in Russia, but also Finland's own national conservation efforts. Displaced logging may cut off Finland's forests from the rest of the biome upon which its native species depend-a potential "boomerang" effect. Our objectives are to: (1) illustrate current trends in logging and nature conservation in northern Europe, (2) demonstrate limitations of the current approaches of nature conservation, and (3) suggest a more holistic approach to nature protection, reconciling forest ecosystem protection with consumption through improvements in forestry practices, technologies, consumption patterns, and broad scale conservation planning.

\section{Boreal forests}

The boreal forest ecosystem (also called taiga), comprising a third of all forests, is predominant across northern North America and Eurasia, and is characterized by a high abundance of coniferous trees (Nikolov and Helmisaari, 1992; Burton et al., 2003). Characteristic tree species include shade intolerant pines (Pinus sp.), birches (Betula sp.), alders (Alnus sp.) and aspen (Populus tremula), and shade tolerant spruce (Picea sp.) and fir (Abies) (Esseen et al., 1997; Burton et al., 2003). Three broadly defined dynamics are relevant for biodiversity conservation in boreal forests: (1) succession after severe stand-replacing disturbances; (2) cohort dynamics related to partial disturbances; and (3) gap dynamics caused by the death of individual trees or small groups of trees (Angelstam and Kuuluvainen, 2004). Naturally dynamic forest stands and landscapes tend to be structurally more heterogeneous and support higher species diversity of many taxonomic groups than managed forest stands (Kuuluvainen et al., 1996; Bergeron et al., 2001; Kuuluvainen, 2002). These more natural stands also tend to have large amounts of dead and decaying wood and old growth, characteristics which support a high diversity of a variety of taxonomic groups, from fungi to wood-boring beetles to woodpeckers (Kruys et al., 1999; Siitonen, 2001; Krankina et al., 2002; Angelstam et al., 2003, 2004a, 2004b; Hautala et al., 2004).

Northern societies extract a wide variety of goods and services from boreal forests. Coniferous species are used for both timber and pulp/paper, while deciduous trees are most valuable as raw material for furniture and interiors. Beyond wood and pulp, boreal forests provide a large number of other products, including mushrooms, nuts, berries, resin, and meat harvested from wild elk (Alces alces) and herded reindeer or caribou (Rangifer taradus), as well as materials for religious or cultural practices (Lund et al., 1998). These forests are a critical carbon sink and play a large role in global climate dynamics (Liski et al., 2003; Chapin et al., 2004), and help moderate water quality in freshwater lakes and streams (Carignan et al., 2000).

\section{Forests of Finland and northwest Russia}

\subsection{Finland}

Boreal forests are the most predominant land cover type in Finland, covering two-thirds of the country. Likewise, the Finnish forestry industries are an important part of the national economy, responsible for roughly $25 \%$ of Finland's exports and 5\% of its GDP (MCPFE, 2003; Finnish Forest Industries Federation, 2005). Products are exported largely to western European countries such as the UK, Germany and the Netherlands; less than $10 \%$ of Finnish value-added products, such as paper and lumber, is used domestically. Wood consumption of Finnish industries has increased steadily, more recently based on imported wood (Fig. 1a). Finnish logging companies procure about one-tenth of their raw material from Russia, and Finnish-based companies have also recently established mills in Russia.

In northern Finland, forest stands are on average larger than in the south, and large tracts of old growth forest have been protected in northern Finland, surrounded by a mosaic of logged to mature forests. Fifty-five percent of forestry land is owned and managed by a governmental agency, the Finnish Forest and Park Service (Metsähallitus) (Finnish Forest Research Institute, 2004). Depending on prevailing tree species, habitat type and geographic location, forests are harvested on a rotation of 60 (birch) to 150 (pine) years, and efforts are made to leave some trees and dead snags for biodiversity (Hyppönen et al., 2001). Northern Finland's forests are highly valued domestically for recreation and aesthetics, and serve as an important ecological connection between the forests in Sweden and Norway to those in Russia. Almost 20\% of forestry land in northern Finland has been placed in protected areas, in which logging is prohibited or limited 

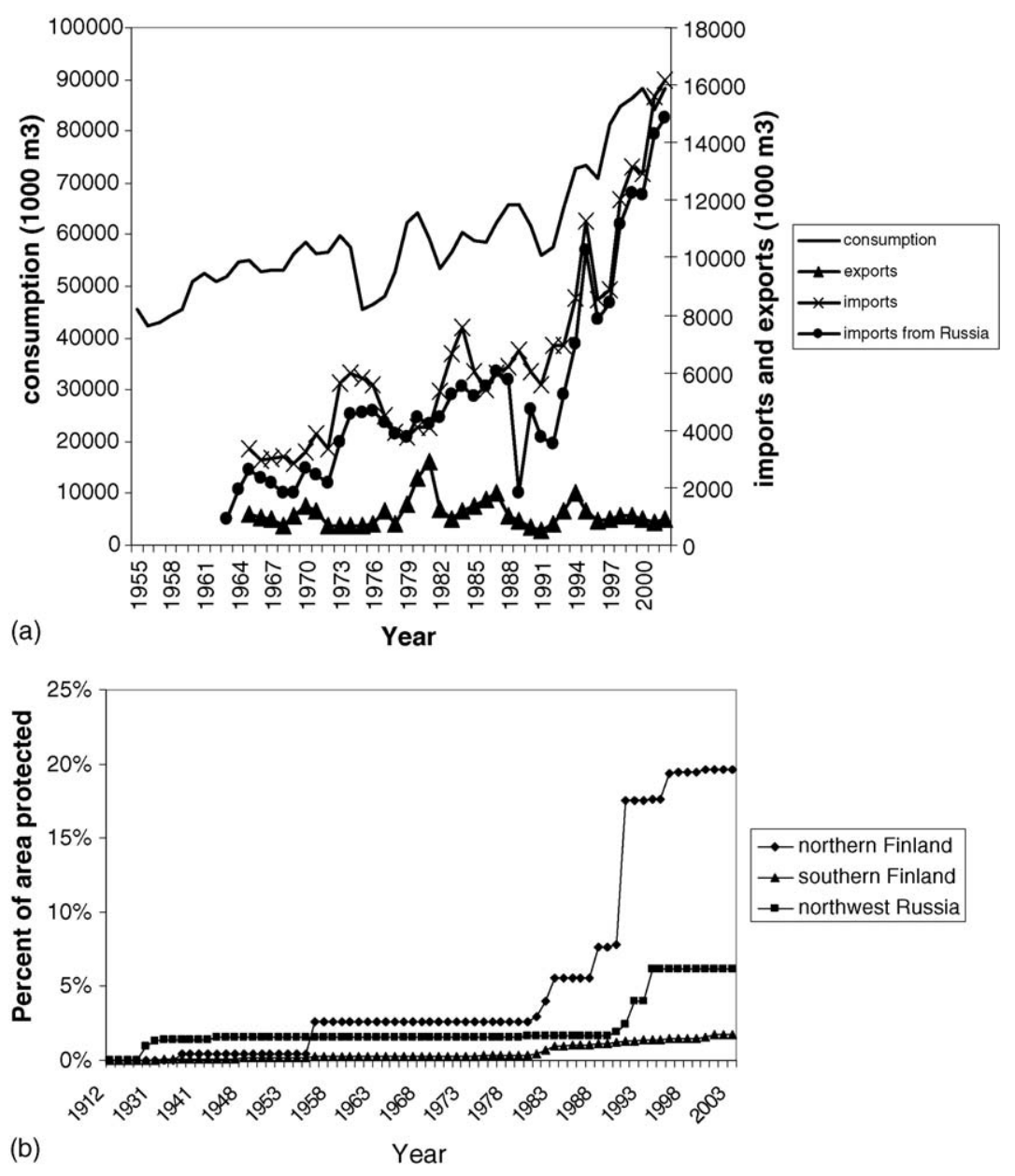

Fig. 1 - Annual (a) imported industrial wood (roundwood, pulpwood, sawnwood, and wood residues) from Russia (ca. 30$40 \%$ of Russian total was from northwest Russia), as compared to Finnish domestic consumption and export. (Source: European Forest Institute), and (b) protected area (national parks and nature reserves) in northern and southern Finland, and northwest Russia. In some of the Russian national parks included in this figure, portions of the park are managed for economic harvests of wood, up to almost $100 \%$ of the park area (Pisarenko et al., 2001). Data for Finland include some nonforested protected area. Regional level parks and reserves in Russia are not included in this graph. (Sources: European Nature Information System, European Environment Agency; Finnish Forest and Park Service (Metsähallitus), Kopylova, 1999a. Northern Finland is delinated by Kainuu, Pohjois-Pohjanmaa, and Lappi Metsähallitus districts).

(Finnish Forest Research Institute, 2004; Fig. 1b). The intact forest remnants along the border between Finland and Russia also offer the advantage, like the Scandinavian and the Ural Mountains, that their north-south direction can contribute important connectivity for conservation scenarios during future climate change.

Due to the less severe climate, southern Finland has a higher complement of native species than northern Finland, but also higher human population density and a longer history of land management. Land is privately held in much smaller (and on average, younger) forest stands; 73\% of forests are privately owned (Finnish Forest Research Institute, 2004). Private forest owners typically enter into contracts with logging companies, who harvest and transport the harvested logs to mills. Outside of the small-protected areas, forests are intensively managed and support few old-growth specialist species. Due to high forest fragmentation at the landscape level, protected areas have a low probability of supporting a full complement of native species in the long term (Virkkala et al., 1994; Hanski, 2000; Gu et al., 2002).

As native forest species have become increasingly endangered (Rassi et al., 2001), demands for additional protection of forests in Finland have been strengthened. In 2004, the government of Finland spent over 50 million euros (US \$62 million) of public funds for the purchase and maintenance of areas reserved for nature protection in Finland, including forest and non-forest habitat (Statistics Finland, 2004). The Finnish Forest and Park Service has developed a large-scale landscape ecological forest-planning scheme for public forests throughout Finland (Hallman et al., 1996; Elmqvist et al., 2004). The program includes actions such as prescribed burning and the conservation of ecologically valuable areas, including dispersal and migratory corridors. However, even though Finnish citizens have expressed a high willingness to pay for domestic nature protection (e.g. Lehtonen et al., 2003), the actual contributions of private citizens to conservation have 
remained low. Utilization of wood for industries in reality outweighs conservation priorities in virtually all stands. The logging interval in a stand is typically 20-30 years, because commercial thinning is a common practice whereby some trees are removed from relatively young stands at age 20-30 years to concentrate tree growth to fewer and larger stems.

Due to the high proportion of privately owned land, higher population density, and culture of "multiple use" of forests, the effective area of forestry land statutorily protected from logging in southern Finland (1.1\%) is substantially lower than in northern Finland (Fig. 1b). To increase the protected area in the "south", where commercial harvests would be postponed or excluded, a program called The Forest Biodiversity Program for Southern Finland ("METSO program") was initiated in 2002, outlining 17 types of government-financed policies aimed at increased biodiversity conservation on both public and private land in the south (Ministry of Agriculture and Forestry, 2002). Some of these policies have been in existence for over a decade, while others in Finland and elsewhere are in pilot phases (Tikka and Kauppi, 2003). Efforts are also made to take biodiversity into account in private commercial forests. The Forest Act (1093/96) obliges landowners to save or carefully manage certain habitat types, such as small ponds or fertile patches of herb-rich forests that are assumed to support species with specific requirements (Tikka, 2003).

\subsection{Northwest Russia}

Over half of the boreal forests on the planet occur in Russia, providing $20 \%$ of global wood biomass (Moiseyev et al., 1999; Burton et al., 2003). The industrial forest sector accounts for approximately 4\% of Russia's GDP (Moiseyev et al., 1999). Russian forests are state-owned and are in general leased to both domestic and foreign logging companies for timber harvest, through contracts lasting from 1 to 49 years (Dudarev et al., 2002). Forest management policies, including sustainable harvest and reforestation, often differ between regional governments, and therefore display a wide variation in the quality of post-harvest forests in terms of wood production and biodiversity conservation. Although the use of more economically efficient auctions is increasing (Kopylova, 1999a), the prevalent system of flat stumpage fees typically values Russian wood products far below world prices (Backman, 1998; Pertti Veijola, personal communication). Law enforcement regarding logging practices has sometimes been difficult (Nilsson, 2002).

The northwest Russia area encompasses 10 regions and republics: Pskov region, Arkhangelsk region, Republic of Karelia, Novgorod region, Republic of Komi, Leningrad region, Kaliningrad region, St. Petersburg, Vologda region, and Murmansk region (Dudarev et al., 2002). The forest industry in this area is responsible for over a third of the annual forest exports from Russia, predominantly to European markets, including Finland (Backman, 1998). Russian mills use primarily coniferous species for lumber; deciduous species are exported to Finnish pulp mills (Fig. 1a). Finnish logging companies harvest and export all species for mills in Finland, although Finnish-based companies have recently established mills in northwest Russia. As the region has few roads, the majority of logging has historically occurred along railways and rivers, used to transport logs to mills (Dudarev et al., 2002). Russian logging practices are different than Scandinavian practices; Russian practices rely more heavily on clearcutting, and active forest regeneration has been less frequent (Dudarev et al., 2002). These practices have created remarkably different landscapes between Fennoscandia and Russia, where large mature and old growth forests are sharply delineated by large clearcut areas in various stages of succession (Burnett et al., 2003; Kalliola et al., 2003; Fig. 2). A transformation of the landscape in parts of northwest Russia, from a coniferous forest-dominated landscape to one that is a patchwork of coniferous and deciduous forests, has substantial consequences for the species composition of ecosystems there (Angelstam and Dönz-Breuss, 2004; Shorohova and Tetioukhin, 2004), especially with respect to exotic and invasive species (Danilov et al., 2003).

Wildfire, which is virtually absent in forests of Finland and Scandinavia, is an element of forest dynamics in Russia. The difference between the two areas is partly a result of efficient fire monitoring and control in Scandinavia and Finland. Fuel load is greater in Russia, associated with the abundance of woody debris and vegetation structure (Krankina et al., 2002).

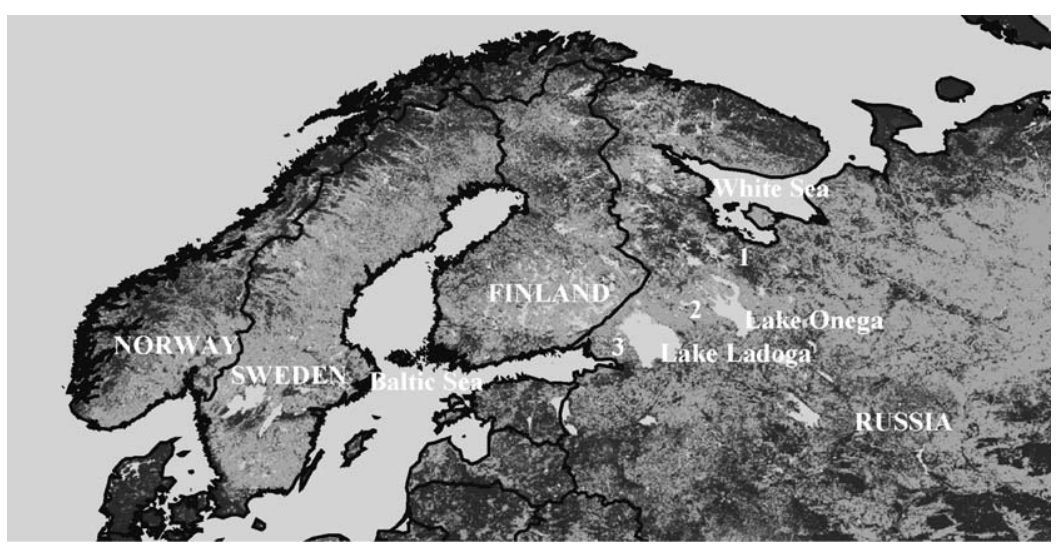

Fig. 2 - Different patterns of land ownership and forest management practices have resulted in markedly different landscapes between northern and southern Finland and the Russian Republic of Karelia. Two critical corridors (1 and 2) link forests in Fennoscandia to the rest of the boreal forest ecosystem in Russia. Corridor 3 is dominated by urban (St. Petersburg) and agricultural land use. Figure modified from Mayer et al. (2005). 
Wallenius (2004) suggests that ignition practices also make a difference. Fire intensity of boreal forests varies between large-scale stand-replacing fires and scattered ground fires (Goldammer and Mutch, 2001). The fire regime has major impacts on species composition.

Over 135 national parks and strict federal nature reserves protect about 40 million ha throughout Russia, with the majority of these areas located in northwestern Russia, where the majority of the population resides (Filiptchouk et al., 2001). Demand for environmental protection is increasing in Russia, and the government has set a goal of ultimately establishing 71 parks and 150 reserves covering 54 million ha by 2005 (Kopylova, 1999b). However, additional conservation efforts have been complicated by a lack of coordination among environmental and natural resource agencies, sparse data and inadequate administrative oversight and funding (Selikhovkin, 2000; Fig. 1b). Throughout Russia, forests have been divided into three management categories since the 1940's (Pisarenko et al., 2001). Group I includes nature reserves, urban parks, and riparian belts protecting lakes and rivers, and in these forests harvests are ostensibly restricted to only those necessary for stand regeneration and maintenance. Group II and III forests are for commercial use, and while forests in the former group are managed for sustainable harvesting in which annual harvest does not exceed annual growth, forests in Group III are allowed to be clear-cut. In northwest Russia, while the percentage of forests allotted to Groups I and II has been increasing, at least $42 \%$ of the forests in this region are managed as Group III forests (Pisarenko et al., 2001) as of 2004.

\subsection{A potential boomerang effect}

The future effect of logging impacted and/or fire-controlled forests in northwest Russia on the long term richness and viability of conserved forests in Finland is likely to be negative for biodiversity conservation. Fennoscandian forests interact with Russian forests through species dispersal and migration, mainly across three key corridors: two cover roughly $25,000 \mathrm{~km}^{2}$ each between the White Sea and Lake Onega, as well as between Lake Onega and Ladoga Lake; and a $9330 \mathrm{~km}^{2}$ corridor south of Ladoga Lake to the Baltic Sea, partially occupied by the city of St. Petersburg (Fig. 2; Lindén et al., 2000).

Many of Finland's avian species (such as Siberian tit (Parus cinctus), Uimaniemi et al., 2003, and capercaillie (Tetrao urogallus), Liukkonen-Anttila et al., 2004) have large populations in Russia, and therefore efforts to conserve theses populations may be more efficient in Russia than in Finland (Rodrigues and Gaston, 2002). The Russian populations also provide invaluable gene flow for some Finnish mammal (such as the gray wolf (Canis lupus, Ingvarsson, 2002; Flagstad et al., 2003) and bird populations (Liukkonen-Anttila et al., 2004). For rare species in southern Finland, such as the white-backed woodpecker (Dendrocopos leucotos), populations in Russia act as a source for Finland's sink populations (Carlson, 2000). Compared to southern Finland in general, a greater abundance and diversity of native species have been found either in eastern Finland or in northwest Russia (Virkkala et al., 1994; Siitonen and Martikainen, 1994). This is particularly so along the border (Brotons et al., 2003), although a part of this pattern may be caused by natural east-to-west distribution gradients
(Kouki and Väänänen, 2000). Geographical patterns of invertebrate diversity are largely yet to be assessed. If the current logging rates and harvest practices in Russia continue, Northwest Russia will suffer a loss of large and old forest patches. This in turn will reduce suitable habitat area and consequently possible source populations for Finland's ecological communities, thereby degrading the effects of conservation efforts in Finland-the boomerang effect (Mayer et al., 2005).

The potential loss of remaining old growth and/or fireimpacted forest in northwest Russia has prompted conservation efforts by environmental groups and the Finnish government, although most proposed protected areas lie along the Finnish-Russian border in the so-called "Green Belt" (Burnett et al., 2003; Kalliola et al., 2003). In addition to nature reserves, Nordic countries have acknowledged the importance of largescale processes and are moving toward a landscape scale approach to forest management, which attempts to mimic natural disturbance processes to maintain forest connectivity and patch size for species dispersal and persistence (Mönkkönen, 1999; Angelstam and Kuuluvainen, 2004; Elmqvist et al., 2004). Some fairly large national parks and nature reserves have been established or are being planned in northwest Russia, however the current domestication of the matrix surrounding these protected areas may reduce the value of these preserved areas in the long term (Bengtsson et al., 2003).

\section{Discussion}

The current dominant approach to the protection of forest ecosystems in northern Europe can be called a "denial approach". The focus is on locating and setting aside valuable areas and on limiting logging in those areas. This is important but insufficient unless conservation measures are coordinated with improvements in forestry technology, forest industry processes, and consumption patterns. Domestic measures for forest protection based on a "denial approach" can be dangerous, if logging is pushed elsewhere (Sedjo, 1995; Berlik et al., 2002; Mayer et al., 2005). An international context is essential (Rodrigues and Gaston, 2002).

In the 1990s, forest conservation programs in Finland rose concurrently with Finnish imports of logs and pulp (Fig. 1a). Domestic consumption of industrial wood in Finland increased, largely based on imported timber, reflecting that the Finnish forest industry has expanded the procurement area to northwest Russia. This shift in logging activity may degrade the natural forests in Russia, upon which long-term species persistence in Finland may depend. Therefore positive and negative aspects of assigning conservation priority to each area should be considered carefully in the context of a larger, more ecologically relevant scale. We examine a few management and policy options for the region.

(1) Protect northwest Russian forests as corridors, harvest more in Finland. Fennoscandian countries would have an incentive to partner with Russian authorities and environmental groups to assure that northwest Russia's biodiversity is suitably conserved and managed, and timber companies, regardless of country of origin, do not degrade conserva- 
tion efforts. This option would mitigate the potential boomerang effect on Finland's species, although it may leave Finnish populations inadequately protected. If the dispersal of individuals from northwest Russia is insufficient to maintain species populations in Finland, the benefit of this approach to Finnish forest communities is likely to be small.

(2) Protect Finnish forests, harvest more in Russia. Given its higher per capita income, established forest conservation policies, and strong environmental protection agencies, nature conservation in Finland may be more enforceable and socially acceptable. Conservation in northern Finland will allow for large naturally dynamic and old growth forests to be protected, and will improve the connectivity of the Fennoscandian forest as a whole. Conservation in southern Finland will improve protection for more species. While protecting species populations at the edge of their geographic ranges may not be optimal at large scales (Rodrigues and Gaston, 2002), preservation of populations across their ranges can help maintain genetic and behavioral diversity for the species, and the flow of products and services provided by those species for local communities (Luck et al., 2003). However, this approach may not succeed in the long term due to the inevitable loss of species in the remaining small forest remnants in southern Finland (the "extinction debt"; Hanski, 2000) if there is reduced immigration from Russian populations.

(3) Protect Finnish and Russian forests and shift logging outside of the region. The practice of protecting forests at home and harvesting forests abroad is not restricted to Europe (Sedjo, 1995; Dekker-Robertson and Libby, 1998; Berlik et al., 2002). The global trade of both timber and wood products has grown increasingly complex, with some countries importing wood at the same or higher rate as that it exports, and in general richer countries are net importers (Kopylova et al., 1999). Poorer countries tend to devalue their forest resources, producing trade differentials that encourage further harvest and fail to account for increasing scarcity of over-harvested forests (Barbier, 1999). Imported high quality logs from the Russian Far East into China, and from Indonesia (and now Russia) into Japan, are other examples of this dynamic (Yamane, 2003; Mayer et al., 2005). This option might increase the sustainability and biodiversity persistence in both Finland and northwest Russia, but it could shift the negative ecological effects to other countries. Furthermore, this option might merely increase the time lag before the effects of consumption would be felt in Finland and northwest Russia (the boomerang effect).

(4) Reduce overall harvest area, through one or more approaches (Wernick et al., 2000):

- Reduce consumption of industrial wood through decreasing demand, substituting products, or increasing recycling (Dekker-Robertson and Libby, 1998; Ince and Moiseyev, 2002), noting that alternative materials will also have environmental impacts (Sedjo, 1995; Petersen and Solberg, 2005).

- Improve the efficiency of logging practices and industrial processes to require fewer trees per ton of products delivered (Wernick et al., 2000).
- Improve the state of biodiversity in commercial forests through a combination of effective certification, forestry recommendations and landscape level planning that maintains functionally connected conservation areas in a benign matrix (Angelstam et al., 2003), using updated knowledge about habitat loss thresholds for population extirpation and ecological integrity (Angelstam et al., $2004 a, b)$. The greatest demand for certified wood products is in the European Union (Siry, 2002).

- Obtain higher yields of timber when possible from hectares already in use from secondary forests or tree farms on abandoned agricultural land, thus using the minimum amount of land for timber production and sparing land for nature (Fiedler et al., 2001; Fenning and Gershenzon, 2002).

Forest conservation and harvesting decisions (where, how, and how much) must deal with complex ecological and socioeconomic dynamics at several spatial scales. Sustainable decisions will maintain the value, productivity, and biodiversity of forests, perhaps through the development of harvesting methods and patterns which can more closely mimic natural disturbances than current practices (Franklin, 1989; McRae et al., 2001; Angelstam, 2003; Bergeron, 2004). The fourth approach detailed above may allow for the most balanced demand for protected forests and wood production without shifting damage to other areas. However, the economic costs and social consequences of these options will vary in time and space, and therefore a mixture of these options will likely be the most feasible, equitable, and sustainable in many cases.

\section{Acknowledgements}

PMT, PEK, and PKA acknowledge financial support from the Marjatta and Eino Kolli Foundation, Metsämiesten säätiö, and the Stiftelsen Marcus och Amalia Wallenbergs Minnesfond, respectively. Discussions with Pertti Veijola from Metsähallistus, and suggestions from two anonymous reviewers, greatly improved the paper. Policies addressed here represent the opinions of the authors, not necessarily those of the US Environmental Protection Agency.

\section{R E F E R E N C E S}

Adams, W.M., Aveling, R., Brockington, D., Dickson, B., Elliott, J., Hutton, J., Roe, D., Vira, B., Wolmer, W., 2004. Biodiversity conservation and the eradication of poverty. Science 306 , 1146-1149.

Angelstam, P., 2003. Reconciling the linkages of land management with natural disturbance regimes to maintain forest biodiversity in Europe. In: Bissonette, J.A., Storch, I. (Eds.), Landscape ecology and resource management: linking theory with practice. Island Press, Washington DC, pp. 193-226.

Angelstam, P., Dönz-Breuss, M., 2004. Measuring forest biodiversity at the stand scale-an evaluation of indicators in European forest history gradients. Ecol. Bull. 51, 305-332. 
Angelstam, P., Dönz-Breuss, M., Roberge, J.-M. (Eds.), 2004. Targets and tools for the maintenance of forest biodiversity. Ecol. Bull. 51, 510.

Angelstam, P., Kuuluvainen, T., 2004. Boreal forest disturbance regimes, successional dynamics and landscape structuresa European perspective. Ecol. Bull. 51, 117-136.

Angelstam, P.K., Bütler, R., Lazdinis, M., Mikusiński, G., Roberge, J.-M., 2003. Habitat thresholds for focal species at multiple scales and forest biodiversity conservation-dead wood as an example. Ann. Zool. Fennici 40, 473-482.

Angelstam, P., Mikusinski, G., Fridman, J., 2004b. Natural forest remnants and transport infrastructure-does history matter for biodiversity conservation planning? Ecol. Bull. 51, 149-162.

Backman, C.A., 1998. The Forest Industrial Sector of Russia. International Institute for Applied Systems Analysis, Laxenburg, Austria. Parthenon Publishing Group Ltd, New York.

Barbier, E.B., 1999. Timber trade and environment. In: Palo, M., Uusivuori, J. (Eds.), World Forests, Society and Environment. Kluwer, Dordrecht, The Netherlands, pp. 106-117.

Bengtsson, J., Angelstam, P., Elmqvist, T., Emanuelsson, U., Folke, C., Ihse, M., Moberg, F., Nyström, M., 2003. Reserves, resilience and dynamic landscapes. Ambio 32, 389-396.

Bergeron, Y., 2004. Is regulated even-aged management the right strategy for the Canadian boreal forest? Forest. Chron. 80, 458-462.

Bergeron, Y., Gauthier, S., Kafka, V., Lefort, P., Lesieur, D., 2001. Natural fire frequency for the eastern Canadian boreal forest: consequences for sustainable forestry. Can. J. For. Res. 31, 384-391.

Berlik, M.M., Kittredge, D.B., Foster, D.R., 2002. The illusion of preservation: a global environmental argument for the local production of natural resources. Harvard Forest Paper No. 26. Harvard University, Petersham MA, p. 23.

Brachares, J.S., Arcese, P., Sam, M.K., Coppolillo, P.B., Sinclair, A.R.E., Balmford, A., 2004. Bushmeat hunting, wildlife declines, and fish supply in West Africa. Science 306, 11801183.

Brotons, L., Mönkkönen, M., Huhta, E., Nikula, A., Rajasärkkä, A., 2003. Effects of landscape structure and forest reserve location on old-growth forest bird species in Northern Finland. Landscape Ecol. 18, 377-393.

Burnett, C., Fall, A., Tomppo, E., Kalliola, R., 2003. Monitoring current status of and trends in boreal forest land use in Russian Karelia. Conserv. Ecol. 7, art8 (online, accessed April 11, 2005. URL: http://www.consecol.org/vol7/iss2/art8).

Burton, P.J., Messier, C., Weetman, G.F., Prepas, E.E., Adamowicz, W.L., Tittler, R., 2003. The current state of boreal forestry and the drive for change. In: Burton, P.J., Messier, C., Smith, D.W., Adamowicz, W.L. (Eds.), Towards Sustainable Management of the Boreal Forest. NRC Research Press, Ottawa, Ontario, Canada, pp. 1-40.

Carignan, R., D'Arcy, P., Lamontagne, S., 2000. Comparative impacts of fire and forest harvesting on water quality in Boreal Shield lakes. Can. J. Fish. Aquat. Sci. 57 (Suppl. 2), 105-117.

Carlson, A., 2000. The effect of habitat loss on a deciduous forest specialist species: the White-backed Woodpecker (Dendrocopus leucotus). Forest Ecol. Manag. 131, 215-221.

Chapin III, F.S., Peterson, G., Berkes, F., Callaghan, T.V., Angelstam, P., Apps, M., Beler, C., Bergeron, Y., Crépin, A.-S., Danell, K., Elmqvist, T., Folke, C., Forbes, B., Fresco, N., Juday, G., Niemelä, J., Shvidenko, A., Whiteman, G., 2004. Resilience and vulnerability of northern regions to social and environmental change. Ambio 33, 344-349.

Chichilinsky, G., Heal, G., 1998. Economic returns from the biosphere. Nature 391, 629-630.
Davenport, L., Rao, M., 2002. The history of protection: paradoxes of the past and challenges for the future. In: Terborgh, J., van Schaik, C., Davenport, L., Rao, M. (Eds.), Making Parks Work: Strategies for Preserving Tropical Nature. Island Press, Washington DC, pp. 30-50.

Danilov, P., Zimin, V., Ivanter, E., 2003. Changes in the fauna and distribution dynamics of terrestrial vertebrates in the European North of Russia. In: Heikkilä, R., Lindholm, T. (Eds.), Biodiversity and conservation of boreal nature. Proceedings of the 10-year anniversary symposium of the Nature Reserve Friendship. Kainuu Regional Environment Centre, Vantaa, Finland, pp. 175-181.

Dekker-Robertson, D.L., Libby, W.J., 1998. American forest policy-global ethical tradeoffs. BioScience 48, 471-477.

Dietz, S., Adger, W.N., 2003. Economic growth, biodiversity loss and conservation effort. J. Environ. Manage. 68, 23-35.

Dudarev, G., Boltramovich, S., Efremov, D., 2002. From Russian forests to world markets: a competitive analysis of the northwest Russian forest cluster. ETLA Series B 195, Taloustieto Oy, Helsinki.

Elmqvist, T., Berkes, F., Folke, C., Angelstam, P., Crépin, A.-S., Niemelä, J., 2004. The dynamics of ecosystems, biodiversity management and social institutions at high northern latitudes. Ambio 33, 350-355.

Esseen, P.-A., Ehnström, B., Ericson, L., Sjöberg, K., 1997. Boreal forests. Ecol. Bull. 46, 16-47.

Fenning, T.M., Gershenzon, J., 2002. Where will the wood come from? Plantation forests and the role of biotechnology. Trends Biotechnol. 20, 291-296.

Fiedler, C.E., Arno, S.F., Keegan, C.E., Blatner, K.A., 2001. Overcoming America's wood deficit: an overlooked option. BioScience 51, 53-58.

Filiptchouk, A.N., Strakhov, V.V., Borisov, V.A., 2001. Forest and forest products country profile: Russian Federation. Geneva Timber and Forest Study Papers No. 19, UNECE, New York.

Finnish Forest Industries Federation, 2005. Paper and wood (online, accessed March 2, 2005. URL: http:// english.forestindustries.fi).

Finnish Forest Research Institute, 2004. Finnish Statistical Yearbook of Forestry. Vammala. (In Finnish with English abstract, figures and tables).

Flagstad, O., Walker, C.W., Vila, C., Sundqvist, A.K., Fernholm, B., Hufthammer, A.K., Wiig, O., Koyola, I., Ellegren, H., 2003. Two centuries of the Scandinavian wolf population: patterns of genetic variability and migration during an era of dramatic decline. Mol. Ecol. 12, 869-880.

Franklin, J.F., 1989. Toward a new forestry. Am. Forests 95, 37-44.

Goldammer, J.G., Mutch, R.W., 2001. Global Forest Fire Assessment 1990-2000. Forest Resources Assessment Working Paper No. 55, FAO, Rome, Italy, p. 495.

Gu, W., Heikkilä, R., Hanski, I., 2002. Estimating the consequences of habitat fragmentation on extinction risk in dynamic landscapes. Landscape Ecol. 17, 699-710.

Hallman, E., Hokkanen, M., Juntunen, H., Korhonen, K.-M., Raivio, S., Savela, O., Siitonen, P., Tolonen, A., Vainio, M., 1996. Alue-ekologinen suunnittelu. Metsähallituksen metsätalouden julkaisuja 3/1996. Metsähallitus, Vantaa.

Hanski, I., 2000. Extinction debt and species credit in boreal forests: modelling the consequences of different approaches to biodiversity conservation. Ann. Zool. Fennici 37, 271-280.

Hautala, H., Jalonen, J., Laaka-Lindberg, S., Vanha-Majamaa, I., 2004. Impacts of retention felling on coarse woody debris (CWD) in mature boreal forests in Finland. Biodivers. Conserv. 13, 1541-1554.

Hyppönen, M., Härkönen, J., Keränen, K., Riissanen, N., Tikkanen, J. (Eds.), 2001. Pohjois-Suomen 
metsänhoitosuositukset. Pohjois-Pohjanmaan metsäkeskus, Kajaani.

Ince, P.J., Moiseyev, A.N., 2002. Forestry implications of agricultural short-rotation woody crops in the USA. In: Teeter, L., Cashore, B., Zhang, D. (Eds.), Forest policy for private forestry: global and regional challenges. CABI Publishing, New York, pp. 177-188.

Ingvarsson, P.K., 2002. Lone wolf to the rescue. Nature 420, 472.

Kalliola, R., Burnett, C., Suojanen, I., 2003. Contrasting boreal forest landscapes in the central border region of Finland and Russia. In: Heikkilä, R., Lindholm, T. (Eds.), Biodiversity and conservation of boreal nature. Proceedings of the 10-year anniversary Symposium of the Nature Reserve Friendship. Kainuu Regional Environment Centre, Vantaa, Finland, pp. 77-88.

Khanna, N., Plassmann, F., 2004. The demand for environmental quality and the environmental Kuznets Curve hypothesis. Ecol. Econ. 51, 225-236.

Kopylova, E., 1999a. Transition from planning to market economy in Russia. In: Palo, M., Uusivuori, J. (Eds.), World Forests, Society and Environment. Kluwer, Dordrecht, The Netherlands, pp. 331-340.

Kopylova, E., 1999b. Environmental concerns in the Russian forest sector. In: Palo, M., Uusivuori, J. (Eds.), World Forests, Society and Environment. Kluwer, Dordrecht, The Netherlands, pp. 363-366.

Kopylova, E., Zhang, Y., Palo, M., Lobovikov, M., 1999. Russian and Chinese forests, societies and environments in transition. In: Palo, M., Uusivuori, J. (Eds.), World Forests, Society and Environment. Kluwer, Dordrecht, The Netherlands, pp. 321-330.

Kouki, J., Väänänen, A., 2000. Impoverishment of resident oldgrowth forest bird assemblages along an isolation gradient of protected areas in eastern Finland. Ornis Fennica 77, 145-154.

Krankina, O.N., Harmon, M.E., Kukuev, Y.A., Treyfeld, R.F., Kashpor, N.N., Kresnov, V.G., Skudin, V.M., Protasov, N.A., Yatskov, M., Spycher, G., Povarov, E.D., 2002. Coarse woody debris in forest regions of Russia. Can. J. For. Res. 32, 768-778.

Kruys, N., Fries, C., Jonsson, B.G., Lämås, T., Ståhl, G., 1999. Wood-inhabiting cryptogams on dead Norway spruce (Picea abies) trees in managed Swedish boreal forests. Can. J. For. Res. 29, 178-186.

Kuuluvainen, T., 2002. Natural variability of forests as a reference for restoring and managing biological diversity in boreal Fennoscandia. Silva Fennica 36 (1), 97-125.

Kuuluvainen, T., Penttinen, A., Leinonen, K., Nygren, M., 1996. Statistical opportunities for comparing stand structural heterogeneity in managed and primeval forests: an example from boreal spruce forest in southern Finland. Silva Fennica 30, 315-328.

Lehtonen, E., Kuuluvainen, J., Pouta, E., Rekola, M., Li, C.-Z., 2003. Non-market benefits of forest conservation in southern Finland. Environ. Sci. Policy 6, 195-204.

Leppänen, J., Linden, M., Uusivuori, J., Pajuoja, H., 2005. The private cost and timber market implications of increasing strict forest conservation in Finland. Forest Policy Econ. 7, 71-83.

Lindén, H., Danilov, P.I., Gomtsev, A.N., Helle, P., Ivanter, E.V., Kurhinen, J., 2000. Large-scale forest corridors to connect the taiga fauna to Fennoscandia. Wildlife Biol. 6, 179-188.

Liski, J., Korotkov, A.V., Prins, C.F.L., Karjalainen, T., Victor, D.G., Kauppi, P.E., 2003. Increased carbon sink in temperate and boreal forests. Climatic Change 61, 89-99.

Liukkonen-Anttila, T., Rätti, O., Kvist, L., Helle, P., Orell, M., 2004. Lack of genetic structuring and subspecies differentiation in the capercaillie (Tetrao urogallus) in Finland. Ann. Zool. Fennici 41, 619-633.
Luck, G.W., Daily, G.C., Ehrlich, P.R., 2003. Population diversity and ecosystem services. Trends Ecol. Evol. 18, 331-336.

Lund, H.G., Pajari, B., Korhonen, M. (Eds.), 1998. Sustainable development of non-wood goods and benefits from boreal and cold temperate forests. EFI Proceedings No. 23, Joensuu Finland, p. 264.

Mayer, A.L., Kauppi, P.E., Angelstam, P.K., Zhang, Y., Tikka, P.M., 2005. Importing timber, exporting ecological impact. Science 308, 359-360.

McRae, D.J., Duchesne, L.C., Freedman, B., Lynham, T.J., Woodley, S., 2001. Comparison between wildfire and forest harvesting and their implications in forest management. Environ. Rev. 9, 223-260.

Ministerial Conference on the Protection of Forests in Europe (MCPFE), 2003. State of Europe's forests 2003. Vienna, Austria, p. 115.

Ministry of Agriculture and Forestry, 2002. Government decision in principle on an action programme to protect biodiversity in forests in Southern Finland, the western parts of the province of Oulu, and the south-western region of the province of Lapland 2002 (online, accessed April 11, 2005. URL: http://www.mmm.fi/metso/international/METSOprogramme_GOVERNMENT_DECISION_Oct_2002.pdf).

Moiseyev, A., Uusivuori, J., Burdin, N., 1999. Forest industries in the Russian Federation. In: Palo, M., Uusivuori, J. (Eds.), World Forests, Society and Environment. Kluwer Academic Publishers, Dordrecht, The Netherlands, pp. 351-358.

Mönkkönen, M., 1999. Managing Nordic boreal forest landscapes for biodiversity: ecological and economic perspectives. Biodivers. Conserv. 8, 85-99.

Myers, N., Mittermeier, R.A., Mittermeier, C.G., da Fonseca, G.A.B., Kent, J., 2000. Biodiversity hotspots for conservation priorities. Nature 403, 853-858.

Nikolov, N., Helmisaari, H., 1992. Silvics of the circumpolar boreal forest tree species. In: Shugart, H.H., Leemans, R., Bonan, G.B.A. (Eds.), Systems Analysis of the Global Boreal Forest. Cambridge University Press, New York, pp. 13-84.

Nilsson, S., 2002. Experiences of policy reforms of the forest sector in transition and other countries with implications for the Chinese forest sector. IIASA Interim Report IR-02043. Laxenburg, Austria, p. 53.

Petersen, A.K., Solberg, B., 2005. Environmental and economic impacts of substitution between wood products and alternative materials: a review of micro-level analyses from Norway and Sweden. Forest Policy Econ. 7, 249-259.

Pisarenko, A.I., Strakhov, V.V., Päivinen, R., Kuusela, K., Dyakun, F.A., Sdobnova, V.V., 2001. Development of forest resources in the European part of the Russian Federation. European Forest Institute No. 11, Leiden, The Netherlands.

Prendergast, J.R., Quinn, R.M., Lawton, J.H., Eversham, B.C., Gibbons, D.W., 1993. Rare species, the coincidence of diversity hotspots and conservation strategies. Nature 365 , 335-337.

Rassi, P., Alanen, A., Kanerva, T., Mannerkoski, I. (Eds.), 2001. The 2000 Red List of Finnish Species. Ministry of the Environment and Finnish Environment Institute, Helsinki (in Finnish with English summary).

Rodrigues, A.S.L., Gaston, K.J., 2002. Rarity and conservation across geopolitical units. Conserv. Biol. 16, 674-682.

Sedjo, R.A., 1995. Local logging, global effects. J. Forest. 93, 25-28.

Selikhovkin, A., 2000. Conservation and management of animal populations in the Russian forest management system. Ann. Zool. Fennici 37, 299-306.

Shorohova, E., Tetioukhin, S., 2004. Natural disturbances and the amount of large trees, deciduous trees and coarse woody debris in the forests of Novgorod Region. Russ. Ecol. Bull. 51, 137-147. 
Siitonen, J., 2001. Forest management, coarse woody debris and saproxylic organisms: Fennoscandian boreal forests as an example. Ecol. Bull. 49, 11-41.

Siitonen, J., Martikainen, P., 1994. Occurrence of rare and threatened insects living on decaying Populus tremula: a comparison between Finnish and Russian Karelia. Scand. J. Forest Res. 9, 185-191.

Siry, J.P., 2002. Today and tomorrow of private forestry in Central and Eastern Europe. In: Teeter, L., Cashore, B., Zhang, D. (Eds.), Forest Policy for Private Forestry: Global and Regional Challenges. CABI Publishing, New York, pp. 81-93.

Sohngren, B., Mendelsohn, R., Sedjo, R., 1999. Forest management, conservation and global timber markets. Am. J. Agr. Econ. 81, 1-13.

Statistics Finland, 2004. Finland's Natural Resources and the Environment 2004 Review (online, accessed March 2, 2005. URL: http://www.tilastokeskus.fi/tk/tt/ymparisto_en.html).

Tikka, P.M., 2003. Conservation contracts in habitat protection in southern Finland. Environ. Sci. Policy 6, 271-278.

Tikka, P.M., Kauppi, P.E. (Guest Eds.), 2003. Special issue: protecting nature on private land-from conflicts to agreements. Environ. Sci. Policy 6, 328.

Uimaniemi, L., Orell, M., Kvist, L., Jokimaki, J., Lumme, J., 2003. Genetic variation of the Siberian tit Parus cinctus populations at the regional level: a mitochondrial sequence analysis. Ecography 26, 98-106.

Virkkala, R., Rajasärkkä, A., Väisänen, R.A., Vickholm, M., Virolainen, E., 1994. The significance of protected areas for the land birds of southern Finland. Conserv. Biol. 8, 532-544.

Wallenius, T., 2004. Fire histories and tree ages in unmanaged boreal forests in eastern Fennoscandia and Onega peninsula. Academic Dissertation, University of Helsinki, Faculty of Biosciences, Department of Biological and Environmental Sciences and Faculty of Agriculture and Forestry, Department of Forest Ecology, Helsinki, Finland, p. 31.

Wernick, I.K., Waggoner, P.E., Ausubel, J.H., 2000. The forester's lever: industrial ecology and wood products. J. Forest. 98, 814.

Yamane, M., 2003. Underlying causes of forest loss in the AsiaPacific region. In: Inoue, M., Isozaki, H. (Eds.), People and forest-policy and local reality in Southeast Asia, the Russian Far East, and Japan. Kluwer, Dordrecht, The Netherlands, pp. 3-32.

Audrey L. Mayer is an Ecologist at the US Environmental Protection Agency, Office of Research and Development, National Risk Management Research Laboratory. She received a PhD in Ecology and Evolutionary Biology from the University of Tennessee, Knoxville, and held postdoctoral positions at the University of Cincinnati and the USEPA. Her research spans several areas, including: multidisciplinary sustainability indices; managing urbanization impacts on aquatic and terrestrial communities; and bird conservation, particularly land use/land cover effects at multiple spatial scales on terrestrial bird communities. She took up a senior research position at the Synergos Research Centre, University of Tampere, Finland in January 2006.

Pekka E. Kauppi is Professor and Chair of the Environmental Science and Policy at the University of Helsinki, Finland. He received his $\mathrm{PhD}$ in Forest Ecology at the University of Helsinki, Finland. His primary research areas include environmental policy, industrial ecology, conservation of biodiversity and forest ecosystems, climate mitigation and adaptation, and equitable and sustainable land use. He has served as a Visiting Scholar at the International Institute for Applied Systems Analysis in Laxenburg, Austria, and director of the Finnish Acidification Research Program in the Ministry of the Environment. He is an author of 150 professional articles in journals, books, and conference proceedings.

Päivi M. Tikka is a Research Scientist working in the field of nature and environmental protection. She holds a MSc in Ecology and Environmental Management and a PhD in Environmental Sciences, both from the University of Jyväskylä, Finland. Her research focuses on both ecological and social dimensions of nature protection. She is interested in ecologically effective management practices as well as in socially acceptable policy tools for protection. In 2003, she was a Guest Editor (with Pekka Kauppi) of a special issue of Environmental Science and Policy, "Protecting nature on private land-from conflicts to agreements".

Per K. Angelstam is Professor in forest and natural resource management at the Swedish University of Agricultural Sciences' Faculty of Forest Sciences and its School for Forest Engineers. His work focuses on two dimensions of sustainability research. The first is developing performance targets to assess, and tools communicate, the status and trends of different elements of ecological sustainability. The second is to understand and bridge barriers for policy implementation in landscapes with different management and history in Fennoscandia and former Soviet Union countries. He has published 2 books and more than 140 scientific and 70 popular articles, as well as education materials aimed at managers and conservation planners, and two international TV-films. 